\title{
原子力用鋼材の問題点と将来*
}

\author{
藤 村 理 人* $^{* *}$

\section{Future Aspect of Structual Steels for Nuclear Power Plants}

Tadato FujIMURA

\section{1. 原子力発電プラントの開発動向と課題}

フランス，イギリスにおいて，西暦 1956 年（昭和 31 年）ガス泠却型発電炉が運転を開始してから，1977 年 において，世界の運転中の動力用原子炉は 201 基（106 $080 \mathrm{MWe})$ 汇達した。 日本はアメリカ，イギリス，ソ 連に次いで世界第 4 位で，14 基（7990 MWe）である. この発電量は, 1975 年にお汁る日本の全発電量の約 8 \%をまかなつている，日本のエネルギー状勢から考えれ ぽ，年成長 $20 \%$ で 1985 年に $36000 \mathrm{MWe}$ の原子力発 電設備にすることが最低の目標であるが，この目標はな かなか消しい開発環境となつている。

このような背景をもとにして，1985 年より 2000 年に かけての日本のエネルギー状勢の逼迫がほぼ想定される のて，原子力発電所の 1 基の容量は, 図 1 に示すように 急速に大型化されてきた。すなわち 1975 年より運転開 始された発電プラントは1基 800〜 $1100 \mathrm{MWe}$ の大型 発電所で, 化石燃料発電所の最新鋭大型プラントと競う 電気出力となつている.

このような大型原子力発電所の健全性を保証するため には，1次冷却系を構成する圧力バウンダリ*をもつと も重要ふ構造部材と考えて，同部材に使用する鋼材とそ の溶接部の健全性を第1に保証することにしている.

具体的にその保証する方法を述べるならば，まず圧力 バウンダリの破局的破損 (Catastrophic Failure) 確率 を $10^{-7}$ (年·器数) :抑制することにある.この確率は 西暦 2000 年において，世界て 10000 基の原子师が稼 動するであろう之考え，その時点において原子炉の破局 的破損がおきるとしても 1000 年に1回という低い確率 であるという論理で公衆の原子力発電所の安全性につい ての合意を得ようとするものである.

現在原子力発電所において，もつとも恐れられている

*1次掵却系の熱鍮送材（軽水，重水またはガス）の瓦力を閉してめる 棰造部村をいう.

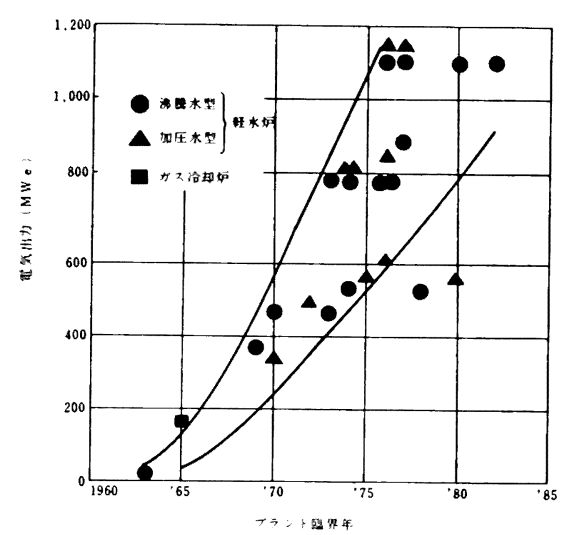

図1日本の発電用動力炉の大型化の傾向

破損は圧力容器の破損である.この原子昵圧力容器は加 圧水型軽水炉の場合, 径 $4.4 \mathrm{~m}$, 高さ $13 \mathrm{~m}$, 容量 180 $\mathrm{m}^{3}$, 重量 $390 \mathrm{t}$ の大型容器であつて, 現在の安全解析 思想では破局的破損を想定せず，代替的に大口径配管の 瞬時破断を最大事故と仮想して安全解析を進めている.

しかしながら大型圧力容器の健全性が，果たして10-7 /(年·器数) という低い破局的破損確率を保証している であろうか. アメリカ原子力安全保証委員会の 1974 年 における報告1によると，原子力以外のプラントにおけ る圧力容器, ボイラの破損確率は，99\% 信頼度におい て, $1 \times 10^{-5} /$ (年·器数) であり, 原子力プラントでは, ASME Code Sec. III および Sec. V のような原子力専 用の最新設計技術を駆使して，圧力容器を建造した場合 $1 \times 10^{-6} /$ (年.器数) であろうと推定している. 図 2 はこ のような調査の結果を図示したものであるが，因みに回 転機械*の例としてタービンの破局的破損によるミサイ ル発生確率2)を比較して示した.タービンの破損確率に

* Active Components といつていろ. ターピン，ポンプなど.

* 昭和 53 年 1 月 27 日受付 (Received Jan. 27，1978)（依頼展望）

** 高温構造安全技術研究組合 (Technical Research Association for Integrity of Structures at Elevated Temperatures Service, Nikko Build., 3-1-9, Kanda-Surugadai, Chiyoda-ku, Tokyo 101) 


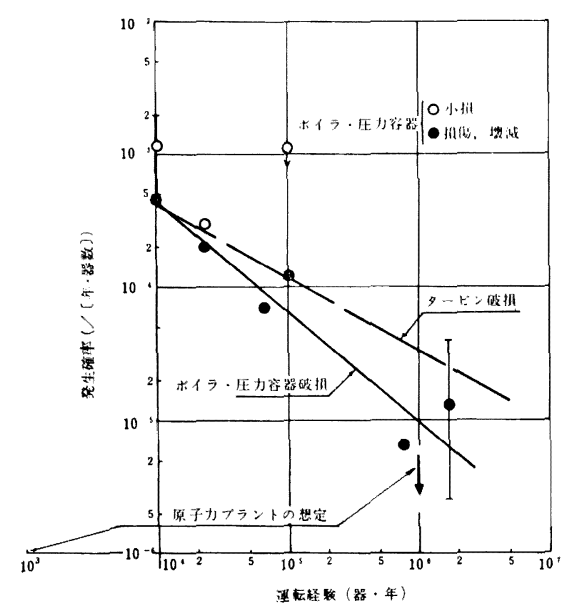

図 2 原子才以外のボイラ・圧力容器の事故の 発生確率

比較すれば，静置機械 (Static Components) である 压 力容器の破損確乘は小さい.

さて原子力プラントにおける圧力容器の破損雄率が， 10-6/(年・器数) であるというのはあくまで情況判断に よる想定である．原子炉正力容器の破局的破損は過去に おいて 1 度も発生していないが，また一方，稼動経験も $10^{3}$ (年·器数) を超えていない. 原子力以外の圧力容器 ボイラの稼動経験が $10^{6}$ (年·器数)になつているのに 比べれば，原子力プラントの稼動はまだをだ末知数で健 全性を確率論的に論ずることは困難である.

原子力技術関係者が原子力発電所の健全性を保証する 上で，もつとも苦しむのはこの点にある.しかしながら 稼動（年·器数）のみは原子力発電所が多数建設され， 運転経駼を積む以外にはいたし方のないものである。そ れにしても西暦 2000 年に打いて，ようやく $10^{5}$ (年·器 数）になるに過ぎない，その時点で破局的破損がゼロで あつても，まだ 10-6/(年·器数) 在直接的に保証するこ とにはならないのである.

このような現状にあつて，圧力バウンダリの破局的破 損確率を $10^{-7}$ /(年.器数)にする技術的努力はきわめて 蕨しいものがある.すなわち現状の原子力技術を 1 桁以 上レベルアップすることが要求されていることを銘記し なければならない。

以上のような前提に扔いて，压力容器鋼材の技術開発 の課題は次のように考元られる.

(1) 鋼種の改良努力

軽水炉圧力容器鋼材についていえば，現用 A 533 B 鋼 をさらに性能のよい鋼材に改良する努力が必要である. それはより高強度, 高䩖性鋼の採用である.大型圧力容器 の製造にあたつては，必然的に大型材料が必要となる。 それは溶接線を極力少なくすることが経済性と健全性を ともに向上するからである。またいつぽう現在使用され

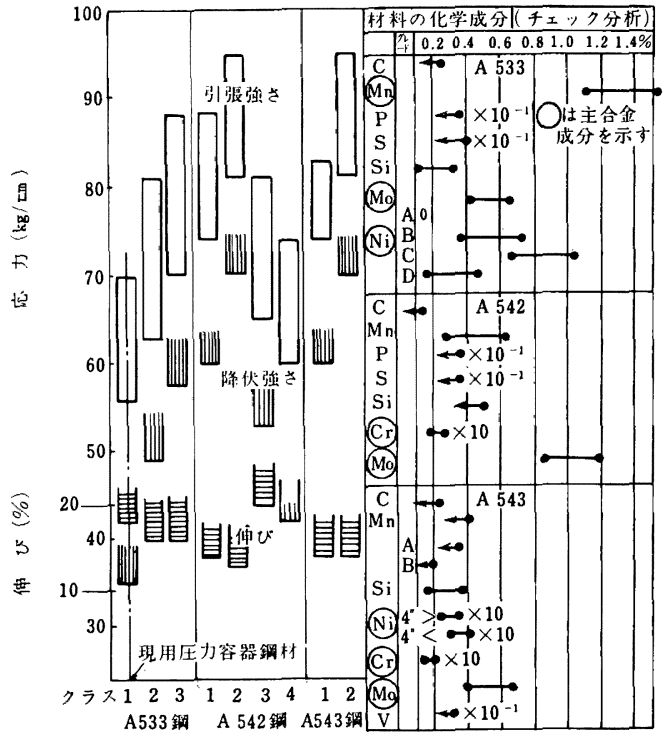

図 3 現用压力容器鋼材と将来候補鋼材

ている耐荷重設計法では, 高強度材料を使用して板厚を 減少せしめ，軽量化をはかるよう指向されている. 図 3 は将来使用されると考えられる候補の鋼材を示したもの である.この 3 鋼種は，いずれも焼入れ・焼もどし熱処 理材で, A 533 鋼 (Mn-Mo-Ni 低合金鋼), A 542 鋼 (CrMo低合金鋼) と, A543 鋼 $(\mathrm{Cr}-\mathrm{Ni}$ 低合金鋼)である. A 533 鋼はアメリカにおいて, ボイラ鋼材として定評のあ つた Mn-Mo 低合金鋼 A 302 鋼の改良材で, Ni が添 加され大型材の烧入れ特性の改良之耐中性子照射特性の 改良が行われた. 同鋼種のグレード B, クラス 1 は現在 軽水炉圧力容器で専ら使用されてきた. クラス 2,3 の 高強度材料は溶接継手の性能がいまだ十分ではない，A 542 鋼は $21 / 4 \mathrm{Cr}-1$ Mo 鋼で，ヨーロッパ，日本では 古くから実績のある容器材料である．この鋼種に類する 鋼材は原子力用以外では相当な実績がある. 課題は焼も どし脆化および水素脆化対策と考えられており，他の性 能は申し分ない.A543 鋼はアメリカ海軍によつて開発 された HY 80 鋼である. 軍用実績において高く評価さ れているが，溶接継手性能を保証するための努力が要求 されている.

\section{（2）鉔造材の使用}

前述したように溶接継手線を少くすることが，大型， 肉厚圧力容器の成形加工において, 健全性を高めること に連がる，とくにタテ溶接継手はフープ荷重（主荷重） をうけもつことになるので，この継手を省略することは 健全性を保証する上で大きな効果がある。すなわち溶接 継手の中性子照射ぜい化間題は，消去することができる し，陌想定による破壊䩓性評価をいちじるしく軽減で きることになる. ここに圧力容器の胴成形を厚鋼板によ 

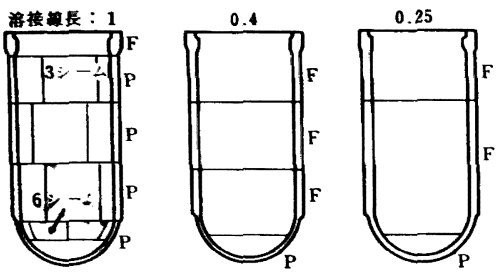

$P$ : 氧板 $F$ : 路造

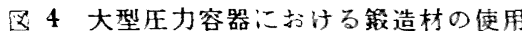
による溶接線の減少 (石川らによる)

るより，艉造材におきかえる方がよい上する結論が得ら れるリング艉造材を使用した場合，図4に示すよう溶 接粎手線を PWR で $75^{\circ}$ 。 堿少することができる3)。こ のこと注，経済性の向上に影響すること流すうまでもな い.

\section{2. 構造設計からみた材料技術への要求}

1.で述ベたように，原子力プラントのコンボーネン トについては専用の構造設計コードをもつている．同コ 一ドは最新の学理と技術の集大成であるぶ，アメリカに お㲿る ASME Boiler and Pressure Vessel Code Sec. III, Nuclear Power Plant Components, Division 1 が代表 的である.日本で注残念ながら，このコードのように体 系的に整合されたすぐれた構造設計基準が作成されてい ない.これはアメリカで注民間の協会, American Society of Mechanical Engineers (AS.ME) ぶ機能的:活動し て設計の合理化に努力しているのに対して，日本では学 会そのものに設計基準を考える積極性がなく，ぬつ設計 コードが法規で律立られているので即応的に合理化がた きず，古い基盤の上に新しい学理，技術をつなくここ文 考えるので矛盾の多、設計基準になつている.このよう な現状は，一方で ASME Code :盲往し，一方では， 古い設計基準も満足させねばならない無䭾の多、設計を 進めるこニ沉つている。

ASIIE Code 自体も必ずしも完全なものでなく，さら に改良きれる心゙きものであるか，少なく々も設計思想: 一貫性がある. この設計思想は保守思想(Conservatism) テある.この保守思想は改良主義であつて，新し：学理 技術が実証的に保証された場合には潮進的に設計基隼: 取入れていく.しか子設計基準の合理化のたかには大型 機器・構造沁おいて材料の選抧，施工技術および検査技 術の間に整合性をもたるばならない，材料のみ進歩して も，その工作技術がおくれているとき亦，優れた材料と いえよ゙もコードに組込むこと至さけている.

構浩設計: お汁万保守思想と合理化の整合:こついて具 体的に述へるならば，その第 1 は設計理論における最大 せん断尤力理論の導入:ある.彷来の設計手法は, 構造物 の延性挙動を前提として, 最大主応力理論を採用してき た。亦わ多軸底力場において, 変形一破損学生ずるか。
表 1 ASME Code Sec. III 亿お汀る許容応力強さ $S_{m}$ の決方

フェライト铜 |オーステナイト铜

銅材: ASTM で規格化した材料，溶接材料はAWS で規格化した材料より選定する。

使用温度限界は $700^{\circ} \mathrm{F}\left(317\right.$ 使用温度限界は $800^{\circ} \mathrm{F}(427$ $\left.{ }^{\circ} \mathrm{C}\right)$ 以下，ボルト銅では ${ }^{\circ} \mathrm{C}$ ) 以下

$800^{\circ} \mathrm{F}$ 以下

1) 常温での最小引張強さ の $1 / 3$

2 ) 高温での引張強さの $1 / 3$

3 ) 常温での最小降伏強さ

の $2 / 3$

4) 高温での降伏強さの $2 / 3$

常温高温それそれの求め方

の低い值をとる.

ボルト铜は除く。

クリーブ速度依存性およびクリーブ破断強さを考慮し た許容応力強さは規定しない。

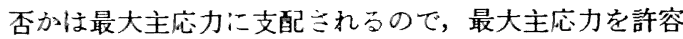
応力值内に抑えこ点ことにより構造設計を進めてきた。 しかしながら最近の学理では最大せん断応力方向に変形 一破損を生ずることが明らかとなつてきた。ここ沉設計手 法に“応力強き(Stress Intensity)”が設計応力指標として 導入きれた。この応力強さは最大せん断応力そのもので はふく,同応力の 2 倍という, 設計手法上のいわぼ便宜的 応力指摽!過突心い.ところがこの応力指標を使用寸れ 法, 従来のコードで定められた“許容応力”を同じ数值 で“許容応力強き”汇読替えるこ上ができるという簡便 さがある。このような合理化が新しい設計法を生むこと によつた。亦方，最近では歪エネルギー論の方がよく構 造物の変形一破損を説明できることが明らかとなつてい るぶ，設計手法之しては複雑になること，疲れ解析など で手にええなく交るなどの理由から，歪エネルギー理論 より保守的ふ心設計之ふる最大せん断応力理論を設計の基 礎理論としている.

第 2 の斬新な構造設計のポイントは許容応力強さを往 来の設計コードのように一つの材料について固定化しな いで，負荷される荷重の破損，変形への影響度に応じて 許容応力値を大きくしたり小さくしたりしていることで ある.もつ上毛重要な負荷応力す制限法, 全般 1 次膜応 力強さ江対する許容応力強さ制限值 $S_{m}$ である.この $S_{m}$ はフェライト铜とオーステナイト铜について表1のよう な決め万になつているが，その前提は設計標準材料によ る構造は区 5 亿示すような変形一破損挙動をするものと 考えている. 古なわち降伏応力強さ $S_{y}$ は引張応力強さ $S_{u}$ の 12 上考无ている. と寸れ衣求为る $S_{m}$ は降伏強 き基準二京れ，引張強さ基準だあれ同じ值となる。オー 


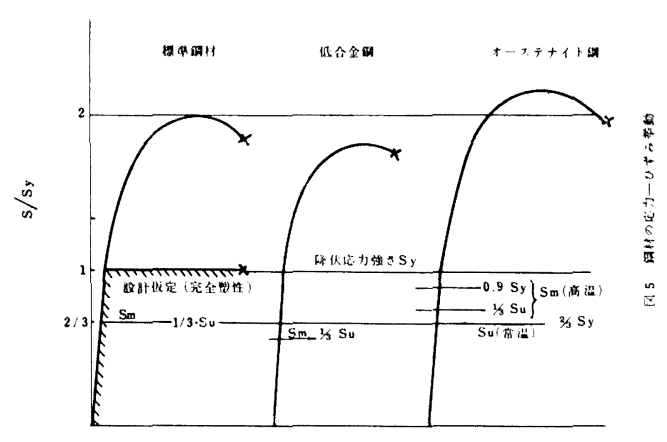

図 5 鋼材の応力ーひずみ挙動?

ステナイト・ステンレス鋼のように $S_{y} / S_{u}$ が 0.5 以下 の材料は高温で $0.9 S_{y}$ を $S_{m}$ 值として導入する場合が ある.これはステンレス鋼が高価材料であることにもよ るが，加工硬化の大きいここ，延性に富み不安定破壊を 生じないことなどを総合的に評洒して，できるだけ高い $S_{m}$ 值を設定して高級材料の使用を容易にしている．い つぽう高強度鋼では降伏強さの高いことにより， $S_{m}$ 值 は有利に設定できるが，延性の不足，不安定破壊の防止 のたてまえから引張強さ基準で $S_{m}$ 值はひかえめに設定 されることになる.

構造物では多軸荷重と多種の種別荷重が作用する。 の一つが曲げ荷重である. 引張荷重（全般膜応力成分） については $S_{m}$ 值を比較的低い值に弾性的に抑えこみ構 造全体が使用寿命 $\left(\sim 10^{5} \mathrm{~h}\right)$ において $1 \%$ 以下の変形に 抑制されるここを設計の目標としている。しかしながら 曲げ荷重は構造物の形状不連続があれば必ず発生する. この曲げ荷重による応力を $S_{m}$ 值で抑えこむ設計は構造 肉厚が過大になり経済性を損うばかりでなく，高温で使 用される部材にいたずらに大きな熱応力（2 次応力）を 発生させることになる. 曲げ応力はいわゆるヒンジ型の 応力で部材の表面では大きな引張応力值となるが，裏面 では圧縮応力となつてバランスする応力である．このよ うな応力による構造物の崩壊は図 6 に示すように, 引張 膜応力のみによる崩壊荷重の 1.5 倍となる. この事実を ふをえて 1 次曲げ応力が作用するとき，その部材に作用 する 1 次引張応力を加えて, $P_{m}+P_{b}<1.5 S_{m}$ という高 い弾性応力ベースの許容応力強さ制限它設定している.

次に 2 次応力が 1 次応力とともに作用する場合は，さ らに応力制限は高く $3 S_{m}$ としている. 2 次応力という のは熱応力とか, 局部発生応力のように, 発生した部材 が変形してしまえば緩和してしまう局部拘束型の応力で ある.すなわち局部の変形に寄与するが，全体変形には 影響することは少ない，例示するならば，圧力容器に取 付けた配管と接続部のノズルの内表面などに発生する応 力である.このような部材では形状の不連続性によつて 高い弾性応力が発生する.しかしながら 2 次応力の高い

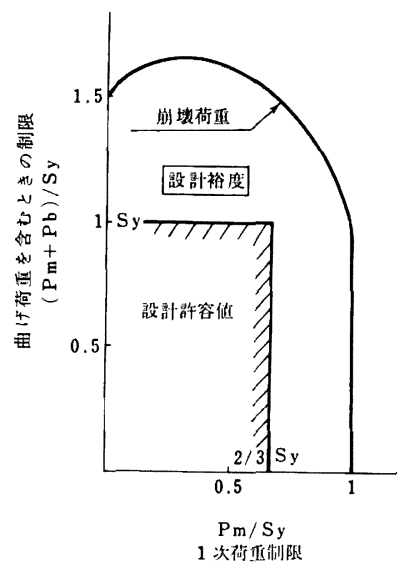

図 61 次引張荷重と曲げ荷重の制限

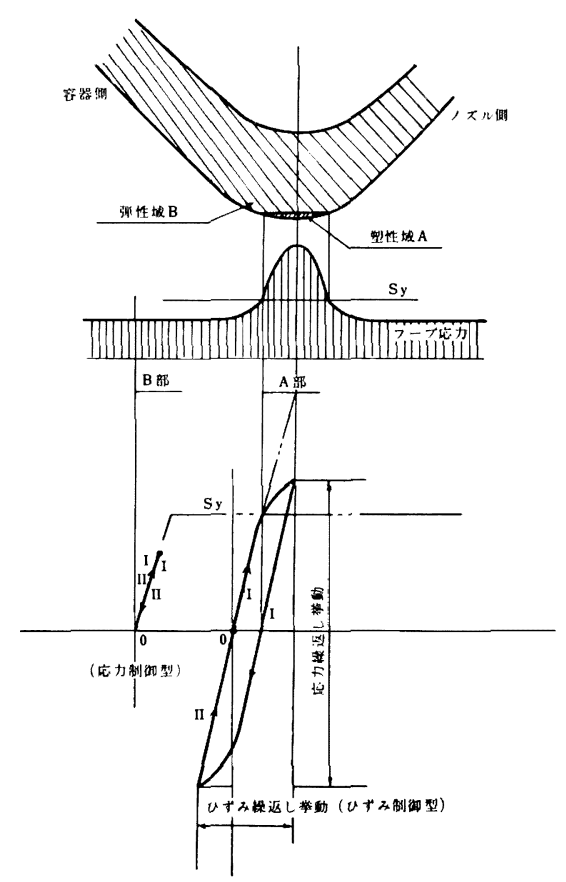

図72 次応力発生部材の応力ーひずみ挙動

部分は局部に限定され，その周辺は 1 次膜応力強さの制 限によつて变形が生じない。図 7 はその状態を示す。こ の場合はシェーク・ダウン効果を期待すれば，局部その ものに繰返し荷重が作用しても，変形は進行性とならな い.シェーク・ダウン効果というのは同図に示すように第 $\mathrm{I}$ 回負荷で局部 $\mathrm{A}$ にのみ大きな 2 次応力が発生しても， 周辺 Bは弾性挙動により, 除荷の場合歪がゼロにもどる.

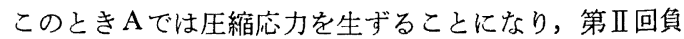
荷以後は, 压縮一引張り挙動となつて $2 S_{y}$ の弾性挙動が 期待できることになる.これがシェークダウン効果であ 
り, 設計に取入れて $3 S_{m}$ という高い弾性応力制限にし ても，大きな変形を生じないことの保証となつている.

第 3 のポイントは異常状態 (Emergency Condition), 損傷状態 (Faulted Condition) に対寸る構造設計法で ある. 異常状態というのは原子妒を緊急停止与る必要の ある場合であるが，このよう文状態は寿命中数多く発生 することは亦・ので，定常または変動状態より高い評価 制限値を許しているが，いつ添うその後の運転に損傷が 残らないことを設計目慓とし、かつ寿命中の異常状態は, 25 回を超えてはならない。さら損傷状態については さらに高い荷重制限值学許している。これはプラントが 壊滅するよう極大荷重が加えられた場合，大きな破壊 に至らず，原子カプラントの究極の安全性を確保するこ とを前提とした設計思想によるものである.

このような高い許容応力強さ制限を使う最新の構造設 計理論は，あくまで主使用する材料の健全性に全幅の信 頼をおいた極限設計手法なのである. 最近の材料製造技 術の進歩により，材料の性能に安定性が保証されてきた ためである・とく沉進歩した非破壊検查技術により，材料 の表層の無欠楩が期待できることを重視している．また 百歩譲つて材料の表層に“きず”があつても延性の十分 な材料は静的荷重に対して切欠き硬化型となつて，大き な劣化効果とならな. し加し繰返し荷重, 衝揧荷重な ぞの動的荷重に対しては “きず”の許容寸法について別 に論じなければならないことはいうまでもない，交た使 用中:ニおける環境に上る材料の表曾の性質劣化は, 現在 の設計コードで汶律しきれ交いので別途評洒している.

\section{3. 将来への課題}

最近原子力発電所における圧力パウンダリにおいて, 相当数の小損事故 (Non-critical Incident) が発表され ている. 小損事故は破局的事故へ発展しないので，現用 の構造設計法を抜本的に改訂する必要はないふ，10-7/ （年·器数）といつた低い破損確率を保証するためには， 小損事故といえども無視するこ之なく，原因を究明し， 処理しなりればならない：システム設計の不備に起因す るものを除き，材料性能の将来一の課題は材料の破壊靬

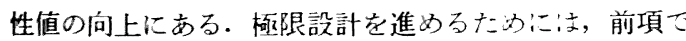
气述べたとおり表層が無欠陥であり，内部欠陥の大きさ が板幥の $2 \%$ 以下の材料が材料メ一カーより压力容器製 造メ一カーに送りこ亡れるこ之が原則となつている。製 造メーカーは成形加工:おいて，溶接継手部の性能が母 材々同等であるこ之を保証し，母材と同椂に欠陥の存在

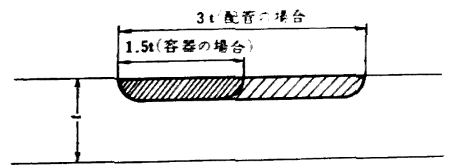

図 8 構造部材の想定欠陥
しないことを保証すること，さらに材料の性能を加工履 歴によつて劣化せしめ校いことに全力を注がねばならな い.このようにして最終的には過生力試験によつて実証 的に構造安全性を保証するのが，現在の圧力容器および 配管構造の品質保証法である。

しかしはから最近の構造物の健全性は図8 に示すように 深さは板厚の $1 / 4$ ，長さは板厚の 1.5 倍(配管では 3 倍) の大きな表潧切欠きを想定して，評価するこ上にしてい る.この想定切久き泣，表層は無欠陥，内部欠陥の大き さ法板厚の $2 \%$ という唡査技術から得られた結果からみ れば，あ杗りにも保守的てある上いえるが，構造強度上 久陷が問題:なる大き夜応力を発生する部材は，検査の 施こし:こい形状をしていることが多く，かつ使用環境 によつて，構造物の供用中に表層にわれが入り，ある程 度進行することは覚悟しなければならない，新しい設計 理論では腐食しろと継手効率の考え方をとらない，これ は極限設計の原則として，強度評価之矛盾するぜい肉を はぶくたわてある。

以上述べたような現状を考えるならば，ある程度大き な想定切久きで構造物の鞄性老評価する保守的方法が理 解されるであろう。ここで加圧水型軽水师 (PWR) の 压力容器の胴部の，中性子照射ぜい化について，ASME Code Sec. III Appendix G で提案している䩓性評価 法について述べてみたい。この評価法はまだ任意採用 基準で問題点をいくつ方分かえている．原子核然料炉 心汇近接している容器胴はほほ $5 \times 10^{19} \mathrm{n} / \mathrm{cm}^{2}(>1 \mathrm{MeV})$ の速中性子照射をうけると想定している。この部材は もつとも破壊䩓性評価が厳しくなるので，ノズルなど 複雑な荷重を発生する部材は取付けず，構造不連続に ならない設計としている．前述のように構造不連続があ る上, 2 次応力が発生し, 曲活応力評価などについて非 弹性解析が必要となること，ピーク応力の繰返しによる 低サイクル疲労解析が必要になるなど設計解析が複雑に 晾る。平坦交胴では 1 次膜応力による引張り応力を主と して 2 軸応力評価で簡易化できる.このような炕心近接 胴には製造した板，鍛造材のう亏，もつ之も材質のよい 鋼材をあてることになつている。この部材について破壊 靶性值 $K_{1}$ を保守的に評価するため，コードでは $K_{\mathrm{IR}}$ 曲 線を設定している．本来， $K_{1}$ 值は鋼種によつて異なる が, 現在ではA533 B 銅が压力容器鋼材として専用され ているので，KIR 曲線は同龬でつくられている。 $K_{\mathrm{IR}}$ は $K_{\mathrm{Ic}} ， K_{\mathrm{Id}} ， K_{\mathrm{Ia}}$ なよ゙種々の定義による破壊鞄性值のなか てでえめな值を採用している。この $K_{\mathrm{IR}}$ を用いて，

$$
2^{*} K_{\mathrm{Im}}-K_{\mathrm{It}}<K_{\mathrm{IR}}
$$

という評価を行う。すなわ方器胴江発生する 1 次膜応 力成分と熱応力成分 $\left(K_{\mathrm{It}}\right)$ の和が $K_{\mathrm{IR}}$ より小さくなる ような $K_{1}$ 值の範囲内で運転または試験をせよというこ とになる。原子炉の運転温度は $300^{\circ} \mathrm{C}$ 前後であるから，

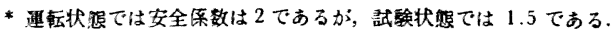




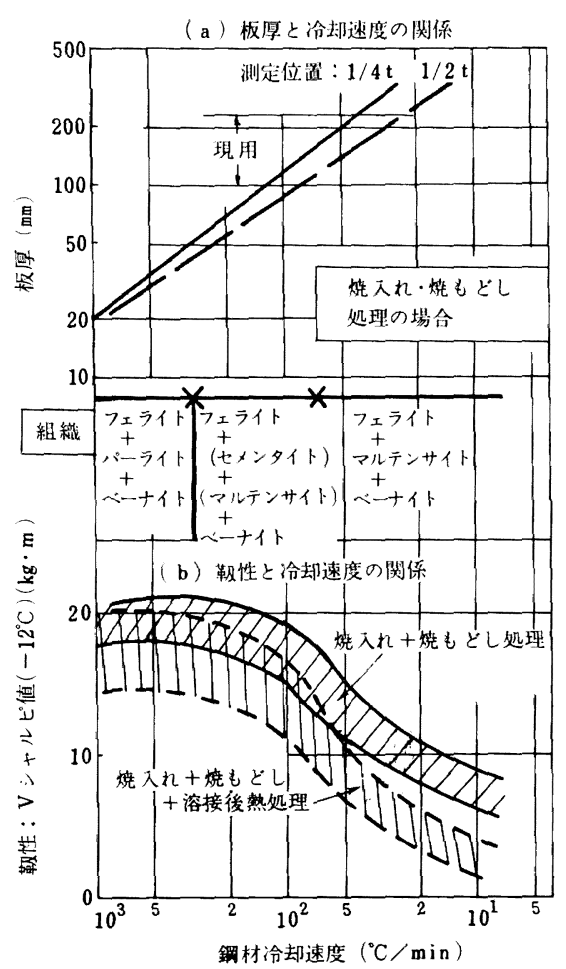

図 9533 B 鋼の冷却速度と鞄性の関係

この温度での $K_{\mathrm{IR}}$ は十分大きく, まず制限値としては 問題にならないから，問題は試駼状態，すなわち完工加 圧試験（設計圧力の1.25倍）と供用中加巵試験（運転圧 カ $\times 1.1$ 倍）の課題である. これら一連の過圧力試験で は，压力容器が大きいことから，高い金属温度に保持す ることは望ましくない.できれば常温で試験することが 望ましい. 常温では $K_{\mathrm{IR}}$ 值は約 $300 \mathrm{~kg} \cdot \mathrm{mm}^{-3} / \mathbf{2}$ であ る. 板厚 $t=200 \mathrm{~mm}$ の容器の場合, 容器のうける応力 強さが $18 \mathrm{~kg} / \mathrm{mm}^{2}$ とすると, $1.5 K_{\mathrm{Im}}+K_{\mathrm{It}}$ は $440 \mathrm{~kg}$ $\cdot \mathrm{mm}^{-3 / 2}$ となり, 常温では加压試験は不可能で $40^{\circ} \mathrm{C}$ 以上の温度で試験をしなければならなくなる．このこと は容器製造メーカーにとつて技術上の課題となるので, 材料製造メーカーにさらに材料の高い $K_{1}$ 值を要求する ことになる。

この ASME Code Sec. III, Appendix G の破壊蜮性 評価法は余りにも保守的であると批判されている.この 評価法でさらに靶性が中性子照射により低下することを 考慮することになれば，枋質保証のための条件があまり にも現実ばなれとなつて経済性はおろか技術的にも対処 のしようが，困難になるかも知れない，とはいうものの 圧力容器の破局的破損確率を $10^{-7} /$ (年·器数) 以下に抑 制するためには破壊鞁性評佂はいちじるしく保守的にな らざるを得ないであろう. A $533 \mathrm{BCl} 1$ 鋼の大型鋼材,

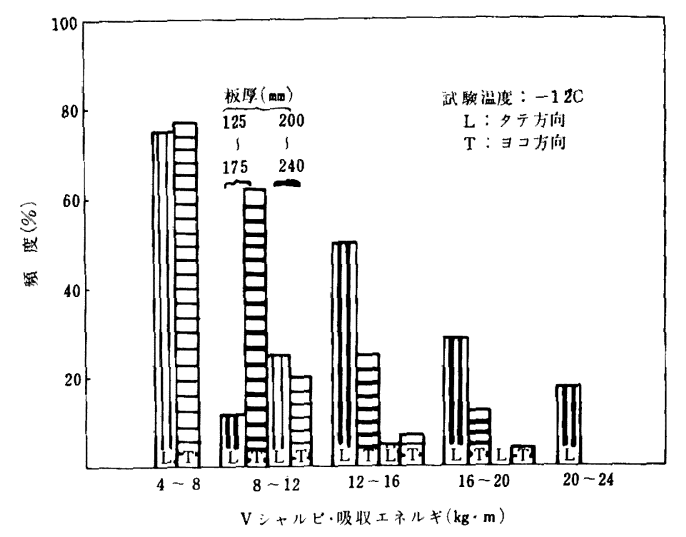

図 10 A 533 B 鋼の板厚による靶性值の比較

とくに板原 $200 \mathrm{~mm}$ を超える鋼材では，図 94)に示す ように焼入れー焼もどし処理において，焼入速度は20～ $40^{\circ} \mathrm{C} / \mathrm{m}$ 程度しか期待できない. 金属組織は（フェラ イトナパーライト十ベーナイト）の混晶となり，䩒性の 劣化が大きくなる.このように A 533 B 鋼の $1000 \mathrm{MWe}$ 級压力容器で使用寸る 200 $250 \mathrm{~mm}$ 超厚板では破壊蜮 性評洒上は限界にきていると考えてよい，压力容器の破 壊靶性を改良するためには，高強度鋼による薄肉化（新 鋼種の採用）とリング鍛造の応用を考えるのが妥当であ るが，著者はさらに原子炉出力を 500 ～ $800 \mathrm{MWe}$ に中 型化して，鋼材の鞋性を保証することを提案している5)。 図 10 は 200〜240 mmの超厚板と 125〜175 mm の厚板 の蔪性をシャルピ衝揧值により比較したものであるが， $200 \mathrm{~mm}$ 以下の厚板がすぐれていることはいうまでもな い.このように考えれば, 材料工学的立場から, 軽水動 力炉の標準化は，500〜800 MWe であることが望まし いといえる。

\section{4. 結誩}

今より 20 年前, 原子力開発の初期において, わが国 の原子力鋼材の研究開発は活発をきわめ, 日本の原子力 鋼材は海外においてもすぐれた評価が与えられた. 現在 $1000 \mathrm{MWe}$ をこす大型原子力発電所の信頼性が保たれ ているのは当時の研究の遺産である.しかしながらここ 5 年, わが国の原子力鋼材に関する研究プロジェクトは 影をひそめ, アメリカに抢ける 超厚板研究計画 (HSST 計画）の成果をトレースしたり, ASME Code の破壊力 学的評価手法を机上で討議しているに過ぎない.このよ うに低迷した原因は，原子力界において原子力用鋼材の 性能向上に対する認識が低下していることにすよるが， 研究開発関係者のリーダーシップの不足が第 1 にあげら れよう.

わが国で，1985 年に累積 $36000 \mathrm{MWe}$ (約 50 基), 2000 年には $300000 \mathrm{MWe}$ (約 400 基）の原子力発電 
所が建設きれて，運転されね芯ならない現状の認識のふ かた，高速增殖妒の建設在含心二，大型原子力用铜材门 研究開発が改めて組立てられることを切望するきのであ る.

\section{交献}

1) ACRS, LS.AEC: Nuclear Eng. and Design,
28 (1974), p. 147

2) S. H. Bush: Nuclear Safety, 14 (1973)

3 ) K. Ishikawa, E. Axdo: Nuclear Eng. Inter., (1977), p. 49

4 ）大西敬三，塚田尚史，島䗁正鈴木公明：鉄と 铜，62 1976，p. 1744

5 ) 藤村理人: 高压力, 15 (1977), p. 281 